\title{
Gravity Modeling Approach for Indonesia's Exports with ten Asian Countries
}

\author{
K. Karno ${ }^{1}$
}

\begin{abstract}
:
The main objective of this research is to study the opportunities and the constraints of Indonesian export sector to various countries in Asia using the Gravity Model approach.

Annual panel data is used to estimate and evaluate the empirical results for the period 19872014. We examine the opportunities and the constraints of the Indonesia's export flows between different locations from Indonesia to other Asian countries.

The results showed that the market size, the investment level, the exchange rates and the inflation rate in trading partner countries can be considered the signals for an export opportunity for Indonesia.

Geographical distance is a factor that has significant influence in Indonesia's trade with other Asian countries.
\end{abstract}

Keywords: Gravity models, export sector, international finance.

JEL Classification: C33; F37.

${ }^{1}$ Lecturer, Faculty of Economic, Borobudur University Jakarta, Indonesia karnoekonomi@gmail.com 


\section{Introduction}

International trade occurs because of two things: (a) Trading is done because each country is basically different from others creating opportunities inn trade; (b) trade is done to achieve economical scale in production, meaning that if each country produces only a certain number of items on a small scale, by trading they can produce goods on a larger scale and therefore beeing more efficient. World trade is a combination of both motives.

According to Ricardian theory a country which has labor productivity that is relatively more efficient than in another country, can obtain comparative better results in producing goods. The test was done by comparing the productivity of labor and the export of each industry between the two countries, namely the USA and the UK (Faisal, 2010). Economic globalization is an increasing interdependent element in the state and in the conditions of economic development among various countries in the world (Sukirno, 2015; Thalassinos and Dafnos, 2015; Thalassinos $e t$ al., 2012; Thalassinos, 2007; Permana, 2017). The factors that encourage the establishment of globalization are: 1) the development of world politics, 2) the growing importance of free-market practices, 3) the development of multinational companies, 4) the development of financial investment or investment portfolios in different countries and 5) the progress in the information technology and transportation fields (Breckova, 2016; Mihola et al., 2016).

With the role of foreign trade in the economy using the free trade system increasing, there are no longer foreign trade barriers. In some countries, exports and imports have a major part of the national income, while in some other countries it is a small part of the national income (Sukirno, 2015). Some advantages from foreign trade are: 1) obtaining the goods that can not be produced by the country, 2) gain benefit from specialization, employment, high productivity. According to Deddy Saleh, General Director of Foreign Trade in the Ministry of Trade in Indonesia, India has shifted Malaysia and Singapore's position in the top five export destination countries of Indonesia. India now occupies the fourth position after China, Japan and the United States. The position shifted due to Indonesia's export performance to India which jumped by 48.2 percent during the first nine months of 2011. Looking at the ratio of exports to total national exports, exports to India reached 8.47 percent during that period while in 2010 exports to India reached only 7.51 percent of the total.

In 2017 exports stood at 13.38 billion US dollars, or going up by 27.71 percent compared to January 2016. Meanwhile, the realization of imports reached 11.99 billions US dollars or going up by 14.54 percent over the same period. By sector, exports from processing industry were dominating with 9.87 billion US dollars or going up by 26.27 percent from the achievement within the same period.

In the period of January-October 2013, the total trade between Thailand and Indonesia reached $16.492,2$ US dollars or increasing by 1.99 percent with total 
exports of 9.381,5 US dollars from Indonesia. Thailand's main commodity exports to Indonesia include agricultural products such as tapioca, agroindustrial products mainly driven by import of sugar, processed foods and beverages as well as manufactured products such as automobiles and accessories, machinery and electrical equipment. Meanwhile, Thailand's biggest imports from Indonesia are crude oil, coal, machinery, vehicle accessories and frozen fish.

Indonesia's main export commodities to South Korea include coal, pulp of wood, and rubber. From South Korea, Indonesia imports electronics and automotive parts. The trend in total trade between the two countries during the last five years (20062010) is positive with a rate of 15.9 percent. Indonesia's trade balance with South Korea from 2006 to 2010 showed that Indonesia has a surplus in trade with this country. Total trade between Indonesia and South Korea in 2010 reached 20.3 billion US dollars with exports value of 12.5 billion US dollars and imports of 7.7 billion US dollars, or by increasing by 57.3 percent compared with the total trade in 2009. The trade balance in 2010 has a surplus for Indonesia amounted to 4.8 billion US dollars, or rose by 43.1 percent compared to 2009 (Indonesian Statistics, 2016).

Based on data from the Philippine Statistics Authority (PSA), in the period of January-December 2015 the country's (Philippines) imports from Indonesia reached 2.927 billion US dollars, while exports to Indonesia amounted only 628.2 million US dollars. This amount is lower compared with the previous year. In 2014, the total imports of Philippines from Indonesia exceeded the value of 3.037 billion US dollars, while the country's exports to Indonesia amounted to 759.658 million US dollars.

"Indonesia's exports to Malaysia in the form of oil and gas products, and also mining and plantation are still much larger than the manufacturing and industrial products," said Indonesian Ambassador for Malaysia, Herman Prayitno. In the period of January to August 2013, the total trade between Malaysia and Indonesia reached 12.94 billion US dollars, with exports from Malaysia to Indonesia reached 7.06 billion US dollars, while imports from Indonesia to Malaysia valued at 5.88 billion US dollars. So the trade surplus to Malaysia is about 1.18 billion US dollars. The rise in Indonesian exports due to improved performance of some major exporting products from Indonesia to Malaysia is remarkable such as coal (up by 38 percent), coconut oil (by 296 percent), palm oil (by 149 percent), and copper refinery (by 712 percent). Other than that, it is also because the increasing exports of some other highly significant products such as garment products, tin and motor vehicle parts. As for the trade with Singapore, the main export items from Singapore are electronics, chemicals, and services. This makes it possible to buy natural resources and raw materials that Singapore does not have.

The study uses panel data on bilateral relations between Indonesia's exporter with the countries of export destination in Asia such as China, Japan, Hong Kong, South Korea, India and also ASEAN member countries. The research aims to analyze the 
opportunities and constraints of export in the export destination countries. Opportunities and obstacles can be seen from the variables used such as market size, public purchasing power, economic growth, the role of FDI investment, exchange rate, inflation, cost of transportation and the role of ASEAN and APEC cooperation relationship.

\section{Literature Review}

\subsection{Exports}

According to Mankiw (2012), exports are goods and services produced in the country to be sold abroad. When the South Korean car maker Hyundai, assemble the car and sell it to Malaysia, the transaction is an export for South Korea and an import for Malaysia. According to Dornbusch (1987) export is the foreigners demand for our goods.

Export activity is trade by releasing the goods from the customs territory of one country to another by meeting the applicable provisions (Djauhari, 2007). Usual export provisions include: (a) trading licenses, either as an individual or a legal entity; (b) exporters must know the exporting items banned by the Government or must have export permission from the Government; (c) exporters must know certain country exports that are prohibited by the Government.

International trade occurs for two reasons: (i) countries trade because they are basically different from each other in production and consuming structures; (ii) countries trade to achieve economic scales in production. That is if a certain country produces a number of specific items, with trading it can produce goods at a larger scale and therefore it will be more efficient. World trade is a blend of both motives.

\subsection{Gross Domestic Product (GDP)}

Gross Domestic Product can be defined as the value of goods and services produced in a country in a given year (Sukirno, 2010). Moreover, Gross Domestic Product can be defined as the total market value of a country's output. It is the market value of all final goods and services produced over a given period of time by all factors of production located in a country (Karl at al., 2003). Mankiw (2012) defined Gross Domestic Product (GDP) as the market value of all final goods and services produced in a country in a given period.

GDP sums all various types of products into a single measure of an economic activity value. To do this, GDP uses market prices. GDP includes all goods produced in the economy and sold legally in the market, this does not include illegal drugs and illegal activities. GDP does not include transactions involving goods produced in the past as well as intermidiate products used for the production of a 
final product locally. GDP measures the value of production within the limits of the geographic area of a country in one year period or in a quarter (quarterly GDP).

\subsection{Per Capita Income (PCN)}

The per capita income is derived from the Gross National Product (GNP) in a given year divided by the population of a country throughout the year. GNP can be seen from several prospectives. The concept of GNP is that it can be used in calculating the per capita income by the government of a country either as the form of Gross Domestic Product (GDP) or Gross National Product (GNP). With that, per capita income can be calculated using the following formula:

$P C N=\frac{G N P n}{P n}$

PCN : Per Capita Income in year $n$

GNPn : Gross National Product (GNP) in year $n$

Pn : Population in year $n$.

\subsection{Economic Growth (GDPGR)}

The rate of economic growth shows the real GNP growth rate in the country under question. The cause of economic growth is the change in the available resources of capital and labor (Dornbusch, 1987). When the economic growth rate is high, production of goods and services will increase, thus allowing an increase in the standard of living. High growth rates will generally reduce the level of unemployment by expanding employment opportunities. Determination of the standard of living depends on its ability to produce goods and services, while productivity depends on physical capital, human resources, natural resources and mastery of science and technology (Mankiw, 2012).

Economic growth is the process of increasing the production of goods and services in the economy. An economy is said to be growing when the total GDP in real terms is higher than in the previous year. The increase in total production is defined as the increase in GDP or GNP of a region or a country. To calculate the rate of economic growth we can use the formula: (Fitr, 2007)

$\mathrm{G}=\left(\mathrm{GDP}_{1}-\mathrm{GDP}_{0}\right) / \mathrm{GDP}_{0} \times 100$

where

$\mathrm{G} \quad$ : real growth rate (percentage)

$\mathrm{GDP}_{1} \quad$ : real National Income calculated based on current prices in year 1

$\mathrm{GDP}_{0} \quad$ : real National Income in the previous year

\subsection{Foreign Direct Investment (FDI)}


Multinational company is a giant company that runs, owns and also controls its business operations or business activities in more than one country (Todaro, 2006). Foreign investment is an investing activity to do business in the Republic of Indonesian territory, that can be made by a foreign investor using foreign capital or a joint venture with a domestic investor (Eiteman, 2010).

The definition of foreign capital covers only the direct foreign capital investments undertaken by or under the provisions of the Constitution and is used to run the company in Indonesia in the sense that the owner of the capital directly bears the risk of the capital investment (Constitution Law No. 1 year 1967 about Foreign Investment).

Foreign investor is an individual citizen of a foreign country, foreign corporation, and/or foreign government that do investments in the territory of, for example, the Republic of Indonesia. Foreign capital is capital owned by foreign countries, foreign individuals, foreign enterprises, foreign legal entities, and / or Indonesian legal entities that are partly or wholly owned by foreign parties.

A Multinational Corporation (MNC) is a corporation that has operations in more than one country (Timothy, 2002). The Organization for Economic Cooperation and Development (OECD), formulated that: "Direst investment is meant by the acquisition of sufficient part of the company in undertaking to ensure its control by the investor". While Somarijah formulate foreign direct investment as follows: "Foreign Direct Investment involves transfer of tangible or intangible assets from one country to another for the purpose of use in the country to generate wealth under the total or partial controll of the owner of the assets ", i.e., direct investment requires capital transfers either tangible or intangible from one country to another country and intended for use in that country in order to make a profit under the supervision of the owners of capital, either totally or partially. For the portfolio investmet OECD formulates that: "Portofolio investment is meant purchase of stocks and bonds in an undertaking on a scale not sufficient to transfer control to the investor".

Indirect investment is generally a short-term investment including transaction activities in the capital market and in the financial markets. These investments are referred as short-term investments because they make buying and selling of shares and/or currency in a relatively short period of time, depending on the fluctuations in the value of shares and/or the currency they wish to trade. These investments are made through the stock market by investing in instruments such as stocks and bonds. The main purpose of indirect investment, in general, is that investors are not establishing a company, but simply buying stocks for the purpose of re-saling. The goal of gaining profit in short period of time in the form of capital gains by the sale and purchase of shares in stock securities is considered as indirect investment.

\subsection{Inflation (INFL)}


Inflation is the rise of prices of goods ans services continuously (Nopirin, 2009). This means that the prices of various goods and services can rise by a certain percentage, affecting the general price level to a certain extend which refers to inflation. It may happen that the increase is not the same in all goods and services however the average effect in the general price level will increase accordingly. One time increase, is not considered as inflation it must run for the whole year. This general price increase is measured by using an index known as the price index.

Some of the price indeces that often used to measure inflation, among others are (Nopirin, 2009): (a) the cost of living price index; (b) the Wholesale Price Index c) the GNP deflator. The cost of living price index measures expenses for the purchase of goods and services by households for living. The Wholesale price index focuses on a number of items on huge trade level. Usually the price index change is in line with the cost of living index. GNP deflator includes the amount of goods and services included in the calculation of GNP as follows:

$G N P=\frac{\text { Nominal GNP }}{\text { Real GNP }} \times 100$

Nominal GNP : Nominal Gross National Product on the basis of price market Real GNP : Gross National Product at constant prices.

Other definitions of inflation based on their cause are as follows. (i) Demand pull inflation; this type of inflation stems from an increase in total demand. The increase in total demanders will raise the prices and production; (ii) Cost push inflation; usually marked by rising prices and declining production. This situation arises with a decrease in the total supply as a result of increased production costs. The increase in production costs, in turn, will raise prices and decline production. If this process runs continuously, cost push inflation will rise. Karl and Ray (2002) say that "Inflation is a rise in the overall price level, it occurs when prices rise simultaneously. We measure inflation by looking at a large number of goods and services and calculate the average price increase for some period of time".

Inflation can be defined as a continuous incresing process of prevailing prices in an economy (Sukirno, 2010). The factors that cause inflation are: (i) the level of aggregate expenditure; (ii) the increase in workers'wages. To measure the rate of inflation we can use the following formula:

$$
\text { Inflation rate }=\frac{\text { Price level }\left(\text { year }_{t}\right)-{\text { price level }\left(y e a r_{t-1}\right)}_{\text {price level }\left(\text { year }_{t-1}\right)}}{100}
$$

The price level which included in inflation, conceptually is price level measured as a weighted average of the goods and services in the economy. In practice, measuring the overall price level by creating a price index, which is the average price of the 
consumer or the producer. Inflation is the increase in the prices of goods that are general and persistent (Pratama, 2008).

\subsection{Exchange Rate $(\mathrm{X})$}

Exchange rate is the exchange value between two different currencies (Nopirin, 2009). Sukirno (2010) states that foreign exchange rates indicate the price or value of the currency of a country expressed in the currency of another country. Foreign exchange rates may also be defined as the amount of domestic money needed, which is the amount of rupiah that is needed, to obtain one unit of foreign currency. Exchange rates indicate that 1.00 US dollar is equal to 8.400 Indonesian Rupiah, means that to obtain 1 US dollar the required amount of Indonesian rupiah is Rp 8.400 .

An exchange rate is an expression of the value of one country's currency in terms of another country's currency. It specifies how many units of one country's currency can be exchanged for one unit of the other country's currency, (Timothy, 2002). Exchange rate or currency exchange rate is an expression of one country's currency value against another country's currency value. Specifically how the units of one country's currency can be exchanged for one unit of another country's currency.

\subsection{Distance (DIST)}

Geographical distance can cause nations changes from exports (the trade) to invest abroad in order to reduce transportation and production costs (Gopinath and Echeverria, 2004). This means investment partners can be encouraged to invest directly in Indonesia with the purpose of reducing the cost of transportation, cost of information or to serve customers better. The domestic market, or close to a larger market, might be more attractive to investors compared to the smaller or further market. Furthermore, an open country with advances in transport density and a short distance from the market could attract investors even though surrounded by smaller markets.

\subsection{Regional Integration (ASEAN and APEC)}

ASEAN (Association of South East Asian Nations) is an economic cooperation between ASEAN countries, including Indonesia, Malaysia, Philippines, Thailand, and Singapore. Economic cooperation between ASEAN countries is expected to strengthen the company in the ASEAN economies, where the demand for goods and services fulfilled by the ASEAN countries and the rest of the importing trade can come from countries outside ASEAN.

APEC (Asia-Pacific Economic Cooperation) is an economic cooperation between Asia-Pacific countries. With this partnership, it has led imports and exports between the countries concerned. Regional integration is political or semi-economic and governments are pursuing integration expectations to reduce barriers between 
members and political uncertainty. Regional integration evaluate the effect of preferential investment agreements between country members and shows the consolidation and the effectiveness among the group members.

This regional integration measures the security interests of Indonesia from trading partners and the level of political alliance or friendliness between the parties involved. As a result, trading partners may want to join regional integration associations such as ASEAN and APEC to gain higher returns. By joining APEC and ASEAN, trading partners have a better opportunity to establish contacts with businesses in Indonesia and further enhance their trade relations with Indonesia. Market potential is important for economic integration that has a direct impact on internationalization by reducing transaction and information costs.

\section{Hypothesis Testing}

\subsection{GDP effect on Indonesia's export to ASEAN countries}

Based on research results by Moudy (2011), GDP has a positive effect on Indonesian exports, as well as other results by Bouedi (2013), Sabyasachi (2013), Suresh (2014), Pakasa (2010), Sarwoko (2009), Anggi (2013), Marlani (2013), Mahfouz (2010), Nguyen (2013), Shaista (2013), Alleyne (2014), Souad (2013), Barry (2008), and Yuventus (2014).

Thus, a large economic size in the export destination countries will increase the exports of Indonesia. Due to these factors, there is a very large market potential as an attraction of Indonesian exports. It can be said that the importer partners hope to generate more profits through mass production with marginal production costs that are lower in Indonesia. With this prospective we can state the hypothesis as follows:

H1: GDP (gross domestic product) excerpt effect on Indonesia's export to ASEAN countries.

\subsection{CAP effect on Indonesia's export to ASEAN countries}

Research results by Moudy (2011) shows that CAP has a positive effect on exports, as well as those by Bouedi (2013), Sabyasachi (2013), Suresh (2014), Pakasa (2010), Sarwoko (2009), Anggi (2013), Marlani (2013), Mahfuz ( 2010), Nguyen (2013), Shaista (2013), Alleyne (2014), Souad (2013), Barry (2008), and Yuventus (2014).

Per capita income has a positive effect on Indonesia's exports to ASEAN countries. Based on the estimated coefficient of per capita income, that is positive, meaning that ASEAN countries, such as China, India, South Korea, Hongkong and Japan has an increase in the per capita income, so that the people's purchasing power is strong enough to buy the goods (both domestically produced goods and imported goods). 
H2: CAP (per capita income) excerpt effect on Indonesia's export to ASEAN countries.

\subsection{GDPGR effect on Indonesia's exports to ASEAN countries}

According to research results by Moudy (2011) economic growth has a positive effect on exports, as well as the results by Bouedi (2013), Sabyasachi (2013), Suresh (2014), Pakasa (2010), Sarwoko (2009), Anggi (2013), Marlani (2013), Mahfouz (2010), Nguyen (2013), Shaista (2013), Alleyne (2014), Souad (2013), and Barry (2008).

Economic growth enables the improvement of living standard stated by Yuventus (2014). When the economic growth rate is high, the production of goods and services increased or gets higher that will generally lower the unemployment rate and expanding employment opportunities. Widespread employment would increase the quantity of individuals who earn income, so that the number of people who are buying the finished goods will also increase and the domestic market will also increase. Goods that are not produced domestically, the government or private parties will import to meet the needs of the community. The research hypothesis is:

H3: GDPGR (economic growth) excerpt effect on Indonesia's export to ASEAN export countries.

\subsection{FDI effect on Indonesia's exports to Asian countries}

The function of FDI is investment to produce goods and services abroad. With the decline of FDI, the goods produced and sold will be decreased and the price of goods will become more expensive. Therefore in order to meet the domestic needs ASEAN countries must import goods. This study was supported by the research of Nguyen (2013) and Saints (2013). The research hypothesis is:

H4: FDI (foreign direct investment) excerpt effect on Indonesia's export to ASEAN export countries.

\subsection{Exchange Rate effect on Indonesia's exports to ASEAN countires}

The exchange rate against the USD rise in export destination countries, so that the price of imported raw materials needed for a product also increases, causing the finished goods' price to go up. If the value of Rupiah per USD is lower, then the price of goods exported is lower than the price of domestic goods in export destination countries, this will increase the Indonesia's export. This study was supported by the research of Fani (2016), Aditya (2016), Tumpal (2015), Bonuedi (2013), Ari (2013), Zulkarnain (2013) and Mahfud (2010). The research hypothesis in this study is: 
H5: Exchange Rate excerpt effect on Indonesia's export to ASEAN export countries.

\subsection{INFL effect on Indonesia's exports to ASEAN countries}

The tendency of rising prices of goods in the domestic market of export destination countries is an opportunity for Indonesian exporters to export goods at a cheaper price. This study was supported by the research of Aditya (2016) and Fani (2016). The research hypothesis in this study is:

H6: INFL (inflation) excerpt effect on Indonesia's exports to ASEAN export countries.

\subsection{Distance effect on Indonesia's exports to ASEAN countries}

Geographical distance between exporters' country and the country's export destinations is a significant factor to boost Indonesia's exports to ASEAN countries. The distance in this model reflects transportation costs and insurance costs. The closer the distance between the cities of the exporters' country to the export destination country, the cheaper the transportation export costs compared to longer distances. The results of this study are supported by Moudy (2011), May (2013), Sabyasachi (2013), Helga (2005), Sarwoko (2009), Mahfud (2010), Bonuedi (2013), Bulent (2011), Utri (2013), Nguyen (2013), Laxmi (2013) and Yuventuz (2014). The research hypothesis is:

H7: Distance excerpt effect on Indonesia's exports to ASEAN export countries.

\subsection{ASEAN effect on the Indonesia's exports}

The results showed that the beta coefficient is positive, meaning that if the regional economic cooperation among ASEAN member countries increases, Indonesia's exports to ASEAN countries increased significantly (by 5 percent). This means that ASEAN member countries provide support for Indonesia's exports to ASEAN countries. This research was supported by the result of Shanping (2013) and Subhechanis (2010). The research hypothesis is:

H8: ASEAN (Association of South East Asian Nations) excerpt effect on Indonesia's export to ASEAN export countries.

\subsection{APEC effect on the Indonesia's exports to ASEAN countries}

The results showed that the beta coefficient is positive, meaning that if the regional cooperation among the APEC countries increase, Indonesia's exports to ASEAN countries will increase significantly. This means that the cooperation of APEC member countries support Indonesia's exports to ASEAN countries. This research 
was also supported by the research of Shanping (2013) and Subhechanis (2010). The research hypothesis of this study is:

H9: APEC (Asia Pacific Economic Cooperation) excerpt effect on Indonesia's export to ASEAN export countries.

\section{Theoretical Framework}

The theoretical framework examines the influence of Gross Domestic Product, economic growth, per capita income, foreign direct investment, exchange rates, and inflation towards Indonesian exports to ASEAN countries, which presented in the following Figure:

Figure 1. Theoretical Framework of Research

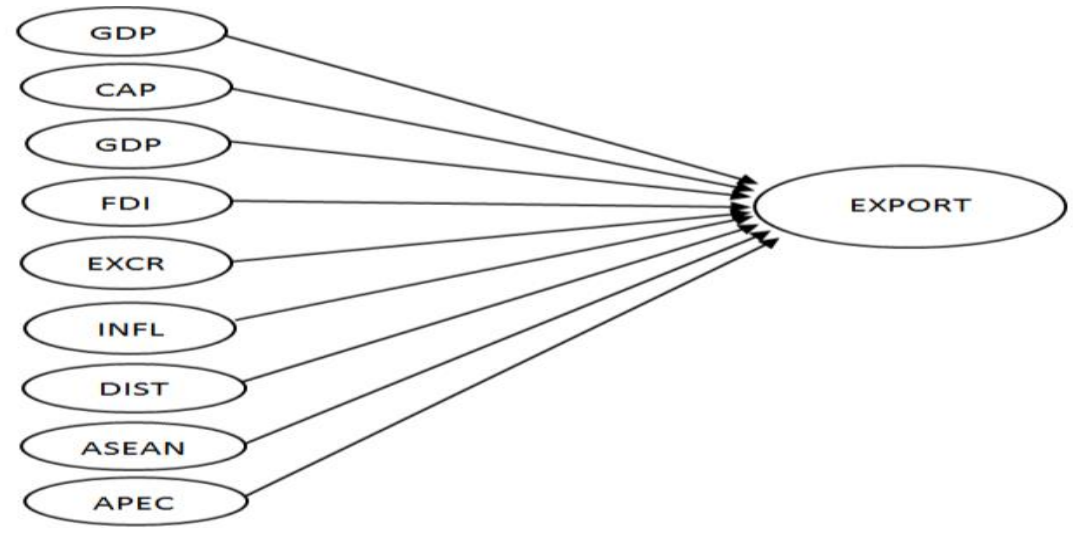
GDP
: Gross Domestic Product
CAP
: Per Capita Income
GDPGR
: Economic Growth
FDI
: Foreign Direct Investment
EXCR
: Exchange Rate
Infl
: Inflation
DIST
: Distance
ASEAN
: Association South East Asia
APEC
: Association Pacific Economics Cooperation

\section{Research Methodology}

The statistical data used in this study were from 10 ASEAN countries for the period 1987-2014. For the sample selection, purposive sampling method was used. The data set is secondary data from international financial statistic reports obtained from the Central Bank of Indonesia. This data set was processed using Gravity Models that aim to determine the effect, both simultaneously and partialy. The proposed 
methodology aims to determine the significance of Indonesia's exports and the influencial factors to ASEAN countries using Eviews-07 software. Data test is using the unit root test with the implementation of the calculations to verify that the proposed method is sufficient. The starting point for the formulation of Gravity Models is expressed as a function of the general specifications of Indonesian exports to ASEAN countries. Gravity main components include market size and geographical distance.

\section{Research Analysis}

In the following Tables 1-3 we present the panel unit root test, the summary of the hypotheses tested and the results from the proposed methodology.

Table 1. Panel Unit Root Test Levin, Lin and Chu.

\begin{tabular}{|l|l|l|l|l|}
\hline Variable & Statistic & Prob & Level & Description \\
\hline Export & $-1,91319$ & 0,0279 & First Different & Stasionery \\
\hline GDP & $-11,9202$ & 0,0000 & First Different & Stasionery \\
\hline CAP & $-8,17691$ & 0,0000 & First Different & Stasionery \\
\hline GDPGR & $-15,0094$ & 0,0000 & First Different & Stasionery \\
\hline FDI & $-11,9202$ & 0,0000 & First Different & Stasionery \\
\hline X & $-7,3828$ & 0,0000 & First Different & Stasionery \\
\hline INFL & $-9,17211$ & 00000 & First Dufferent & Stasionery \\
\hline
\end{tabular}

Table 2. Summary of Hypotheses Test Result.

\begin{tabular}{|l|l|l|l|l|}
\hline Hypothesis & Beta Coefficient & $\mathrm{t}-$ Statistic & prob & Information \\
\hline H1: GDP & 0.602105 & 13.05556 & 0.0000 & Take effect \\
\hline H2: CAP & 0.529857 & 5.869107 & 0.0000 & Take effect \\
\hline H3: GDPGR & 0.079016 & 1.756881 & .0803 & Take effect \\
\hline H4: FDI & -0.03161 & -1.168166 & .2440 & No effect \\
\hline H5: X & 0.123807 & 3.094261 & 0.0022 & Take effect \\
\hline H6: infl & 0.003145 & 0.052921 & .9578 & No effect \\
\hline H7: DIST & -1.405826 & -3.716684 & 0.0003 & Take effect \\
\hline H8: ASEAN & 0.822947 & 2.326041 & .0209 & Take effect \\
\hline H9: APEC & -1.238719 & -2.119118 & .0352 & Take effect \\
\hline H10: Adj R2 & 0.822947 & & & \\
\hline F-Statistic & 123.3978 & & & Take effect \\
\hline Prob-Stat & 0.0000 & & & Take effect \\
\hline
\end{tabular}

Table 3. Hypotheses Test Result.

\begin{tabular}{|l|l|l|}
\hline & Hypothesis & information \\
\hline
\end{tabular}




\begin{tabular}{|l|l|l|}
\hline H1 & $\begin{array}{l}\text { The rising purchasing power of the export destination countries or } \\
\text { the countries' domestic market of export destination could increase } \\
\text { the exports from Indonesia to Asian countries and significant }\end{array}$ & accepted \\
\hline H2 & $\begin{array}{l}\text { The rising per capita income of the export destination countries } \\
\text { will increase the exports from Indonesia to Asian countries and } \\
\text { significant. }\end{array}$ & accepted \\
\hline H3 & $\begin{array}{l}\text { The rising economy growth of the export destination countries can } \\
\text { increase the exports from Indonesia to Asian countries and } \\
\text { significant. }\end{array}$ & accepted \\
\hline H4 & $\begin{array}{l}\text { The declining FDI of the export destination countries will increase } \\
\text { the exports from Indonesia to Asian countries but less significant. }\end{array}$ & Rejected \\
\hline H5 & $\begin{array}{l}\text { The rising exchange rate of the export destination countries will } \\
\text { increase the exports from Indonesia to Asian countries and } \\
\text { significant }\end{array}$ & accepted \\
\hline H6 & $\begin{array}{l}\text { The rising inflation of the export destinationcuntries will increase } \\
\text { the exports from Indonesia to Asian countries but less significant }\end{array}$ & Rejected \\
\hline H7 & $\begin{array}{l}\text { The decrease of distance between the capital city of the export } \\
\text { destinationcountries and Indonesia, can increase the exports from } \\
\text { Indonesia to Asian countries and significant }\end{array}$ & accepted \\
\hline H8 & $\begin{array}{l}\text { The increase of regional relations among ASEAN member } \\
\text { countries can increase the exports from Indonesia to Asian } \\
\text { countries and significant }\end{array}$ & accepted \\
\hline H9 & $\begin{array}{l}\text { The regional decreased relations among the countries member of } \\
\text { APEC can increase the exports from Indonesia to Asian countries } \\
\text { and significant }\end{array}$ & accepted \\
\hline
\end{tabular}

The first hypothesis (H1) states that the GDP have a positive influence on the export of Indonesia to ASEAN countries. The size of the market acts as the key factor for exports to ASEAN countries. GDP represents the amount of the purchasing power, which is indicated by the amount of production throughout the company to buy raw materials, payment of labor for the production, payment of administrative services, public and sales staffs. This large market has a very large-scale production, so that ASEAN countries require raw materials, products in process and finished goods from Indonesia. The results showed that the GDP impact on Indonesia's exports to ASEAN countries is quite significant at 1 percent significance level.

The second hypothesis (H2), states that the CAP, per capita income, which is a measure of purchasing power per individual, affects the exports. This happens because if the per capita income has a high value, then the purchasing power for goods and services will be very strong. The results showed a positive beta coefficient meaning an increase in per capita income results an increase of Indonesia's exports to ASEAN countries and this effect is significant.

The third hypothesis (H3) is on GDPGR. It is a measurement of economic growth in the country over the years, both a growth in importing country and the exporting country. If economic growth is an indicator that the welfare of the society increases, 
the purchasing power of goods produced and sold in ASEAN countries from year to year increase. The results showed that the beta coefficient is positive; it means that there is a significant economic growth in ASEAN countries to increase Indonesia's exports to those countries and the effect is significant.

The fourth hypothesis (H4), FDI, states that the function of FDI is investment to produce goods and services, so as to compare the amount of money circulating with the amount of goods available, the price of goods can be stabilized or the price may go down. Low or high prices of goods will affect exports and imports. The results showed that the beta coefficient is - 0.03161, meaning that if FDI decreased by 1 point then Indonesia's export to ASEAN countries rise by 0.0311 points, but this effect is not significant.

The fifth hypothesis (H5) states that if the currency exchange rate of one country's export destination against the US dollar fluctuates then the result in foreign exchange reserves of the country also fluctuates. If the exchange rate fell against the USD then the raw materials imported become low in value so the price of goods produced and sold are also low. But on the contrary, if the currency exchange rate of export destination countries rise against the USD, then the value of imported raw materials will rise and production costs and selling prices also rise. In a condition like this, the export destination country is better by importing goods from other countries rather than manufactures in the country because the prices of goods are cheaper. The results showed a positive beta coefficient which means any exchange rate rosen by 1 percent, will increase Indonesia's exports to ASEAN countries by 0.12 percent and this result is significant.

The sixth hypothesis (H6) INFL states that inflation shows an increasing trend of the price of goods in the export destination countries. The increase in the price of goods in export destination countries will increase Indonesia's exports to these countries if the price of goods that we exported is cheaper. The results showed that the beta coefficient is positive, it means that an increase of 1 percent in the inflation rate of ASEAN countries (export destination countries), would boost Indonesia's exports by 0.003 percent. However this result is not significant.

The seventh hypothesis (H7), states that the distance between the country of origin and the country of exports destination, including the costs (the cost of transportation, cost of travel risks, insurance costs, etc.) to be paid by companies and charged at rates paid by the consumer. The closer the distance the lower the cost, otherwise the further the distance, the costs borne by the exporter company will be increasingly large. The results showed the sign of beta coefficient is minus, meaning that the decline in distance between the cities of Indonesia's exporters to ASEAN countries' destination affect the increase of Indonesia's export and the effect of this distance by increasing Indonesia's export was significant. 
The eighth hypothesis (H8), states that ASEAN is an economic cooperation between ASEAN countries, which includes Indonesia, Malaysia, the Philippines, Thailand, and Singapore. The economic cooperation relationship between ASEAN countries is expected to strengthen economic corporation in ASEAN, where the demand for goods and services are met by the ASEAN countries, and the rest imports from countries outside ASEAN. The results showed that the beta coefficient is positive, meaning that if the regional cooperation among ASEAN countries increased, the Indonesia's export to the ASEAN countries will also increased significantly, at the level of 5 percent. This means that ASEAN member countries are able to deter Indonesia's export to ASEAN countries.

The ninth hypothesis (H9), states that APEC, economic cooperation between AsiaPacific countries, partnership has led to imports and exports between the countries concerned. The results showed that the beta coefficient is negative, which means that the relationship of cooperation between APEC member countries has decreased, but the APEC countries cannot prohibit or prevent Indonesia's exports to ASEAN countries which gives a significant increase in Indonesia's export. The result is statistically significant.

\section{Conclusion}

Based on the analysis above we conclude the following:

H1: Increased purchasing power in the export destination countries (ASEAN countries), can increase Indonesia's exports to these countries significantly. This result is also supported by the research of Moudy (2011) showing that GDP has a positive effect on exports. Other researches supporting the hypothesis are: Bouedi (2013), Sabyasachi (2013), Suresh (2014), Pakasa (2010), Sarwoko (2009), Anggi (2013), Marlani (2013), Mahfouz (2010), Nguyen (2013), Shaista (2013), Alleyne (2014), Souad (2013), Barry (2008) and Yuventus (2014).

H2: Per capita income has a positive influence on the growing of Indonesia's exports. This result is also supported by Moudy (2011). The research shows that CAP has a positive effect on exports as well as other researches by Bouedi (2013), Sabyasachi (2013), Suresh (2014), Pakasa (2010), Sarwoko (2009), Anggi (2013), Marlina (2013), Mahfouz (2010), Nguyen (2013), Shaista (2013), Alleyne (2014), Souad (2013), Barry (2008) and Yuventus (2014).

H3: Economic growth has a significant and positive impact on Indonesia's exports. This result is also supported by Moudy (2011), Bouedi (2013), Sabyasachi (2013), Suresh (2014), Pakasa (2010), Sarwoko (2009), Anggi (2013), Marlani (2013), Mahfouz (2010), Nguyen (2013), Shaista (2013), Alleyne (2014), Souad (2013), Barry (2008) and Yuventus (2014). 
H4: The decline in Foreign Direct Investments (FDI) affects Indonesia's exports to ASEAN countries. This hypothesis is also supported by research results from Nguyen (2013) and Saints (2013).

H5: Rising exchange rates in export destination countries boosts Indonesia's export. This hypothesis is also supported by Yuventuz (2014), Marc (2011), Zulkarnain (2013), Alleyne (2012), Nguyen (2013), Bonuedi (2013), Ari (2013), May (2013), Subhenhanis (2010) and Yayat (2007).

H6: Rising inflation in the export destination countries influences the rise of Indonesia's exports. The same hypothesis is also supported by the research of Aditya (2016) and Fani (2016).

H7: Geographical distance affects Indonesia's exports. The closer the distance the bigger the positive influence in Indonesian exports. The result of this study is also supported by Moudy (2011), Mei (2013), Sabyasachi (2013), Helga (2005), Sarwoko (2009), Mahfud (2010), Bonuedi (2013), Bulent (2011), Utri(2013), Nguyen (2013), Laxmi (2013) and Yuventuz (2014).

H8: Increasing regional cooperative relations between ASEAN countries have affected Indonesia's exports. This study is also supported by the research of Shanping (2013) and Subhechanis (2010).

H9: Economic cooperation between the country-members of APEC has influenced the Indonesian exports to those countries. The result of this study is also supported by Subhechanis (2010).

\section{Recommendations}

1. The role of the Government in terms of strengthening trade relations with ASEAN and APEC countries.

2. The role of the Government in fostering labor productivity increase in order to lower the production cost and also to have prices that can compete in the international market.

3. The role of the Government in bureaucratic reforms, mainly in the trade sector, so that time and cost can be suppressed to be more efficient.

4. The role of the Government in terms of tax incentives and export credits to encourage exports.

\section{References:}

Breckova, P. 2016. SMEs Export Activities in the Czech Republic and Export Risk Insuring. European Research Studies Journal, 19(1), 84-92.

Damodar, N.G. 2011. Fundamentals of Econometrics. $5^{\text {th }}$ edition, $2^{\text {nd }}$ print, Penerbit Salemba Empat.

Damodar N.G. 2012. Fundamentals of Econometrics. $5^{\text {th }}$ edition, $2^{\text {nd }}$ print, Penerbit Salemba Empat.

Dey-Ancharas, V. 2004. The Determinant of FDI in Comparative Prespective: Is There Bias Against Sub-Saharan Africa, FDI in SSA. Mauritius Research Journal, Department of Economics and Statistic, Faculty of Social Studies and Humanities, University of Mauritius, Mauritius. 
Djauhari, 2007. Guidelines for Export and Import Transactions. $1^{\text {st }}$ print, Penerbit Prestasi Pusta Karya.

Eiteman, 2010. Multinational Financial Management, 1, $11^{\text {th }}$ edition. Penerbit Erlangga.

Eiteman, 2010. Multinational Financial Management, 2, $11^{\text {th }}$ edition. Penerbit Erlangga.

Faisal, B. 2010. Basics of International Economics. $1^{\text {st }}$ print, Penrbit Kencana.

Hamdy, 2005. International Financial Management, $3^{\text {rd }}$ edition. Penerbit Administrasi Yayasan, Indonesia.

Jhingan, 2010. Economic Development and Planning, $1^{\text {st }}-13^{\text {th }}$ Edition, PT Rajawali Grafindo Persada, Jakarta.

Karno, 2013. Factors Affecting FDI into Indonesia, Malaysia, Philippine, Thailand, and Singapore.

Karno, 2014. The Infrastructure to Attract FDI into Indonesia.

Marshall, S. 1982. Capital Investment and Financial Decision. Prentice Hall, Inc., Englewood Cliffs, New Jersey.

Maurice, D.L. 2001. International Finance Book I. Penerbit Andi, $1^{\text {st }}$ print.

Maurice, D.L. 2001. International Finance Book II. Penerbit Andi, $1^{\text {st }}$ print.

Mihola, J., Kotěšovcová, J., Wawrosz, P. 2016. Intensity and Extensity of Firm Development and Dynamic Dupont Analysis. European Research Studies Journal, 19(4), 53-63.

Nachrowi, D.N. 2008. Use of Econometrics Techniques, revision edition, PT Raja Gafindo, Persada.

Nopirin, 2010. International Economics, $3^{\text {rd }}$ edition, $7^{\text {th }}$ print, BPFE, Yogyakarta.

Nurhidayat, 2012. Tax Treaty and Foreign Direct Investment in Indonesia. Finance and Banking Journal, 14(1).

Permana, D. 2017. Toward the Best Model of Strategy Implementation in Indonesian Islamic Banking from the Lens of Strategic Clarity. European Research Studies Journal, 20(4B), 3-15.

Rusdin, 2002. International Business, $1^{\text {st }}$ print, Penerbit ALFABETA, Bandung.

Sadono, S. 2010. Macro Economics: Introduction Theory. $3^{\text {rd }}$ edition, Penerbit PT Raja Grafindo Persada, Jakarta.

Supranto, J. 1991. Statistical Theory and Applications, $1,5^{\text {th }}$ edition.

Supranto, J. 1991. Statistical Theory and Applications, 2, $5^{\text {th }}$ edition.

Thalassinos, I.E. and Dafnos, G. 2015. EMU and the process of European integration: Southern Europe's economic challenges and the need for revisiting EMU's institutional framework. Chapter book in Societies in Transition: Economic, Political and Security Transformations in Contemporary Europe, 15-37, Springer International Publishing, DOI: 10.1007/978-3-319-13814-5_2.

Thalassinos, I.E., Ugurlu, E. and Muratoglu, Y. 2012. Income Inequality and Inflation in the EU. European Research Studies Journal, 15(1), 127-140.

Thalassinos, I.E. 2007. Trade Regionalization, Exchange Rate Policies and EU-US Economic Cooperation. European Research Studies Journal, 10(1-2), 111-118.

Todaro, 2006. Economic Development, translation Aris Munandar, $9^{\text {th }}$ edition, Volume I, Penerbit Erlangga, Jakarta.

Widarjono, A. 2009. Econometrics, Introduction and Applications. $3^{\text {rd }}$ edition, $1^{\text {st }}$ print, Penerbit Ekonisia. 